\title{
Critical analysis of the reality of the Mexican Health System and the Organization of Health Systems in Mexico
}

\section{Estrada Mota Ivonne ${ }^{1}$, Huitzil Huitzil Lourdes ${ }^{1}$, Lazcano Cruz Mauricio ${ }^{1}$, Márquez Plancarte Teodora ${ }^{1}$, Trejo Velasco Nora Yaneth ${ }^{1}$, Villanueva González Reyna Yaneth ${ }^{1 *}$}

\footnotetext{
${ }^{1}$ Estudiantes de la Maestría en Salud Publica del Instituto de Estudios Superiores Elise Freinet.
}

\section{ARTICLE INFO}

Article No.: 022618027

Type: Critical analysis

DOI: 10.15580/GJEPH.2018.2.022618027

Submitted: $26 / 02 / 2018$

Accepted: 10/03/2018

Published: $31 / 03 / 2018$

${ }^{*}$ Corresponding Author

Villanueva González Reyna Yaneth

E-mail: yavadance@hotmail.com

Keywords: Public Health, Organization of Health Systems, Fragmented, Inequality, Universal Coverage
The Health System is the set of activities responsible for intervening in society, its main purpose is health, and is the product of the evolution of more than 100 years that began in Mexico 74 years ago, with the creation of the Ministry of Health and Assistance. Objective. To establish the state of the health system and the Organization of Mexican Health system and the need for Universal coverage of Health Services for the population. Methods. A systematic review of literature obtained from the internet, team work, shared analysis and discussion of the organization theme of Health Systems was carried out. Results. The structure and coverage of the Mexican health system includes the public and private sectors. The first includes social security institutions Mexican Social Security Institute (IMSS), Institute of Security and Social Services of State Workers (ISSSTE), Mexican oil (PEMEX), Secretariat of Defense (SEDENA), Secretariat of the Navy (SEMAR) ), Ministry of Health (SSA), State Health Services (SESA), IMSSPROSPERA Program (IMSS-P), Popular Health Insurance (SPS)]. The private sector includes insurance companies and service providers that work in private clinics, clinics and hospitals, including providers of alternative medicine services. Conclusion. In Mexico, it is questioned whether the population has access to and coverage of Health Systems and although there is an Organization of Health Systems, this is not well organized, and this is a product of the governability of the personalities in charge of Health in Mexico. 


\section{INTRODUCTION}

In order to understand and comprehend the public health and the organization of health system in Mexico with a better vision and efficiency, we will introduce the definition of health system, and give analysis of the coresponsibility and health strategies, and then establish a reflection about how the Mexican health system has started and its evolution until our current days.

To start, it is important to comprehend the concept of co-responsibility in public health; it involves the participation of the community, or, the improvement of the conditions of health involves a mutual feeling from the people as well as from the authorities to improve the health services. Sometimes government promotes the services or programs directed at decreasing the damages that are evident in public health but unfortunately, people do not participate as it is expected.

The design of programs and public policies has been a crucial factor for the improvement of health systems that is why all countries over the world are improving on their systems by including a universal access, equality, quality and justice. ${ }^{1}$ For this goal, courage toward change is required, the attitude and readiness to recognize the importance of individual, familiar and social self-care and the responsibility to guarantee health service access to the community. Encouraging healthy habits and education, removing the passive role ideology as a result and making them action generators to get efficiency and quality. ${ }^{1}$

As part of the educational strategies for public health implemented intentionally from showing photo murals or pictures, it represents in its meaning the selfconstruction of messages generating self-awareness and consciousness, besides, it falls into the generation of co-responsibility in public health, and triggers permanent changes on people's behavior. Drawings and signs represents in its meaning, a way to depict the carefulness that the people consider they must make in their own community, in order to achieve a healthy environment and keep a culture of riskless self-care. Similarly, this reflects the willingness and disposition to keep on learning about any topic referring to public health and can be useful in their daily lives. Men, women, boys and girls describes the presence and steadiness of drawings and the photo murals they have done as a way to learn continuously to live with a better style and better quality of life. ${ }^{2}$

In the publication called "contexto socio ambiental y la educación para la salud en san Andrés Paxtlan, Oaxaca, México" by Ruvulcaba and Cortés $(2013)^{3}$ done in the Cerro Santiago, San Pedro Loma, El Carrizal and La Concepcion, these are communities that belong to San Andres, Paxtlan, Oaxaca, Mexico. The necessities identified, do not allow the correct development of health in this towns. For this reason, we decided to design strategies which are geared towards changing the deficiency in such places; for example, the deficit of the social economical system, education, access to health system, restroom service health service, co-responsibility from the government and the society. ${ }^{3}$

In most of the towns, there is a lack of basic health services like: consumable fresh water, drainage (use of toilets, open-air excreta), health services (based on the fact that a nurse goes every month or more times and a doctor who goes to the community near the main town) even though the town has a lot of resources to change to a social environmental development. ${ }^{3}$

Nowadays, education is a basis of "memorization" besides being deficient and inequitable, therefore, structured strategies were implemented in this towns to generate meaningful learning. It takes us to the necessity to teach based on the verbs; know, comprehend and use. The example of these strategies were photo-murals, pictures, workshops, surveys (house by house, researchers to community) to trigger a reflection about these facts in the towns.

On the other hand, it is important to have an aim in terms of health systems; in Mexico the health system is a group of elements that are roughly linked by a common function, as a list of organizations or people who participate in the production of services, not even coordinated or integrated at all. ${ }^{4}$

How is Mexican health system? Before answering this question, we must talk about the background and the social dynamics. As well as explain the elements which add up the reforms, the system integration of Mexican health reform. And the social impact on public health, checking the prevalence and incidence numbers of sicknesses mortality rates, and the attestation from the users about the quality of quality of health care attention. The situation on public health is getting worse, since it was observed that in 2010, obesity in our country was in the first place nationally, with a bigger number on kids. This data indicates an extra concern of risk for metabolic disorders including diabetes and cancer.

Two modalities appeared in Mexico to health service access:

a) Workers from the formal sector of the economy (private and public) and their families protected by the social security, they are called insured people or beneficiary (Right holders).

b) Peasants, own-account workers, unemployed and even homeless people who are uninsured or "open population".

- The Financial resource

- According to the population number helped out, infrastructure and equipment.

- The participation of employees and employers.

- Differences among all the institutions of the health sector. 
- Insurance of all the beneficiary with a formal job.

- Supposed insurance without job.

- Insurance on health rely on the user's own money.

- Parallel health institutions with big differences in infrastructure.

human resources.

Coverage

Problem-solving ability of health necessities Dependent from social security institutions; IMSS, ISSTE, PEMEX, SEDENA, SSA. Etc. there are differences even per each state.

The inequality on financial per capita for the insured and uninsured population has been decreased. By 2004, the cost per capita per each insured person was 2.4 times more than the one for people without social security, in 2008, this difference was reduced to 1.5 times, it means that per for each peso aimed dedicated to health care, the insured person required 1.5 pesos more to care about his health. The heyday of public health has had an important impact on the improvement of life conditions all around the world, as well as on the epidemiological transition of the standard actions on public health all over the world has had a significant effect on the movement rates of the Morbi-mortality, increasing the life hope when a new baby is born.

However, the attention given to this situation highlights how sickness have arisen in number with a new presentation in the symptomatology for the medical researchers. ${ }^{5}$

Education and public health are directly linked from a biological and social perspective. Thus, in the frame environment-culture, the base of transformation in the conditions of public health is found in biological principles as well as in the respect given to the environment and the concern given to individual health as in social principles; for example, the participation of the tasks in which the mutual effort generates common benefits, creating ecological consciousness is one of the basic objectives that is the outcome from adopting this perspective. $^{6}$

The quality of education conciliates population development. This education must start from the correct use of teaching approaches, from a constructive approach, where the knowledge would be built and the collaboration would be stimulated, for example the collaborative learning in group, task projects, in-group tasks and the application of the theories as the cognitive means in which the generation of the consciousness about the learning were encouraged and on its environmental context, to promote constant improvement in their lifestyle and the quality of their lives. $^{6}$

The administration on health is defined as the application of the management of assets and services through collaborative strategic planning that generates a continuous improvement in the human well-being and this means health. ${ }^{7}$ The management on health hedge directly on the health professional who works as an administrator. When the resources are used in a good way considering the plans and through the correct process including the high-level of knowledge and established goals, it optimizes the process and fastens accessibility to health service. ${ }^{7}$

Training the actors or people in charge to build the public policies, having enough people to cover all the vacant administrative positions according to the social needs and the academic requirement and noting the internal need for improvement in job skills that are a constant requirement to the national issues, so as to impact the local section to get new skills and competencies. $^{7}$

High-quality management of health involves such dynamism, that, it is necessary to implement changes in the everyday feeding habits and even the physical activity or any other aspect that might improve their health condition. Quality is something very simple; it involves having things done well for its development. It is not necessary to be the best manager of health, it is only necessary to have a team that is willing to offer a good services, socially uncompromised, with ethics and values such as responsibility, and knowing how not to put the patients in unnecessary risks. Also, for accessibility to service to be possible, affordable costs must be considered. ${ }^{7}$

When management is done with taking into account all social context where it intends to make promotion of health, it is possible to do an effective strategic plan with the available resources, including education for health, based on constructivism. This will allow improvement on the expected outcomes, pioneering as health managers the application of lifestyles and health conditions of the people that are beneficial, through the teaching-learning process, as part of a strategy prior to the production of habits and permanent skills. ${ }^{7}$

Essential functions of public health:

1. Monitoring and analysis of the situation of population's health.

2. Supervision of public health investigation and risk control, and damages in public health.

3. Promotion of health.

4. Social participation and empowerment of citizens' health.

5. Development of policies, plans and ability of management.

6. Regulation and supervision in public health.

7. Evaluation and promotion of equitable access to the service.

8. Development of human resources and public health training.

9. Guarantee of the quality of individual and collective health service.

10. Investigation, development and implementation of innovating solutions on public health. 
11. Reduction of emergencies and health disaster.

Public health plays an important role in the health system. The main goal is to achieve all these essential functions, and in this way, be able to note the main objectives that enhance the condition of health in towns. Therefore, it should be established and understood who implements the mentioned functions and the responsibility to take correct decisions, taking into account values like; honesty, knowledge, passion and sensibility. If our political leaders lack these values, bad decisions will be taken, and that will affect the achievement of public health. ${ }^{8}$

Among the public health functions, monitoring and analysis of public health situations is very important, supported by the collection of information to evaluate health emergencies, even though there is an epidemiological area to look out for, this is unknown or is always managed for the profit of some people because of the lack of honesty, the lack of social sensibility, and corruption. $^{8}$

The second essential function of public health is the supervision of public health, investigation and risk control, and damages on public health. This has not been done the best way possible because the people who are in these positions have not performed their job correctly, getting the positions because of relation with influenced people, Is causing damages to health in different parts of the country. The population is in a greater way guilty as well, because the people has let the government to adopt a paternalistic role, hindering the development of their own ability for self-care of their health. ${ }^{8}$

Different health programs have been developed in Mexico to battle real health problems so that the population is encouraged to be part of the generation with good health habits and implement hygienic measures that might help to stop the spread of sicknesses, however, they are not implemented because of the lack of an educational model that activates and empowers participants to generate abilities to be able to build up their own knowledge and put into practice their meaningful learning. As long as they do not have qualified people, and educate the population with a constructivist approach, the management of public health cannot take place and the promotion of health will be incomplete. ${ }^{8}$

In terms of the fourth essential functions of public health; social participation and empowering of the people on their health, in this case, the population participates less and less in the decision-making of their own health, causing one of the main barriers of the participation of the communities in programs about prevention, diagnostic, treatment and rehabilitation. ${ }^{8}$

In Mexico, having knowledge about a health system that is prepared to promptly prevent damages caused by disasters and appropriate early rehabilitation helps to have a chain reaction. It is essential to have knowledge about the land where we grow, where we live, and where we were born. The essential functions might be a set of pointers to the health condition of the population in any place in the country. ${ }^{9}$

Finally, other aspects to be considered are social participation and empowerment in terms of health, which is closely related to the "shared responsibility of public health", where the community participates in the conservation and improvement of its health condition along with the authorities assuming a mutual compromise", that is one of the axis to be promoted, if it is pretended to achieve significant changes on public health. $^{10}$

\section{DISCUSSION}

Health system in Mexico has a long term institutional framework with contrasting results in current quality conditions, access and coverage of health services. It talks about a fragmentation of systems, the difference of access, and the quality in the service dependent of indicators of health and poverty. In the Organic law of the federal public administration, in its article 39 fraction $\mathrm{VI}$, it is assigned the function of "Planning, regulating, coordinating and evaluating the national system of health and provided with the correct participation of other agencies and public entities that offer public health, in order to ensure compliance with the public health law". ${ }^{10}$

Public health has a main role in the health and healthiness of the people and communities where they live. It Is a constant co-responsibility between the government and the individuals, each one should do their own share to achieve the goals, with an impact on education through the acquisition of knowledge, learned and implemented in favor of improving health, with good educational strategies so that the population can learn, comprehend and reflect on what is learned as well. $^{1}$

We know that the health system in Mexico is not distributed with regard to financial resources, materials and human resources, otherwise, is segmented without achieving its main goal which is universal coverage. It has specific programs with appropriate approach but unfortunately, they do not reach the places they should reach, or at the moment of their application the steps are not followed correctly. ${ }^{4}$ And the deficient application of such programs is how the population gets costume to the government providing them with all the necessary sources for survival without any effort to achieve it by themselves. So, where is the universality, equity and efficiency of the health service ${ }^{5}$

The health conditions in Mexico has evolved at the same time as the social-economic conditions, the issued that the health system faces nowadays is characterized by 4 overlapped transitions; about necessities, expectations, financial, and resources for health. Fragmentation of health system generates differences in the right access to service and issues in terms of efficiency and the right use of available sources. ${ }^{11}$ 
The management of public health involves knowing about the management of the available resources, and prioritizing the areas in-need. A management of quality of public policies implies coresponsibility of government and community to be able to have the best outcomes. Both the preparation and knowledge of manager in health are important, because they are decision makers. Performing honestly with sensibility, passion and continuous quality and equity to all people who need a kind of health service, this urgent necessity will create a new healthy environment, where co-responsibility of the population and the state would be active and compromised to make a change. ${ }^{8}$

\section{CONCLUSIONS}

Public health is a science and art of preventing sickness disease, making people's life longer and promoting health and efficiency through the organized effort of a population. Its challenge is putting into practice the essential functions of public health, in complete, correct and efficient ways. That contributes efficiently on the improvement of the organization of health system, such as the one in Mexico that currently works as a fragmented system where there are inequity and injustice among the different sectors of population. For such transformation, knowledge as well as investigation is required, which are originated through a high quality of education in both teaching and learning, an education that fulfill the necessary standards of competence. Education is based on observation, questioning, thinking, analysis, formulation of possible solutions, known for constructivist knowledge and constant innovation.

It is important to have a constant practice of values-features such as knowledge, honesty, passion, and sensibility, as they are fundamental requirements for decision makers. This fact would allow the existence of co-responsibility between the community and government, making it possible for the creation of positive environments that permit lifestyle improvements, risk prevention related to the basic sanitation epidemiological emergency, prevention of catastrophic disasters that brings sicknesses as a consequence, family state, thereby the impoverishment of more groups of society joined with a slow economical reaction. With the implementation of the mentioned values, the management of health will allow the development and put into practice sustainable and maintainable programs in all ways. Each problem reflects the growing corruption that exists in Mexico, the lack of values, loss of human sense and ethic shown by authorities and professionals who make the decisions. While those that would rightly fit their positions are a waste of talent and resources and are given irrelevant positions or where they are very limited to be able to enterprise and innovate ideas that can take the population of Mexico out of the inequality and inequity it currently is.

\section{ACKNOWLEDGMENTS}

The authors are grateful with the academic preparation induced by our professors in the Master in Public Health of the High-Studies Institute "Elise Freinet Pachuca De Soto in Hidalgo Mexico.

\section{Declaration of interest:}

The authors declare that there is no conflict on the publishing of this article.

\section{REFERENCES}

1. Sandra Yazmín Cortés Ascencio y Jesús Carlos Ruvalcaba Ledezma. La corresponsabilidad en Salud Pública. Viva Salud para todos. INSP. 2011; 1 41-43.

2. Sandra Yazmín Cortés Ascencio y Jesús Carlos Ruvalcaba Ledezma. Estrategias de educación para la Salud Publica. Viva Salud para todos. INSP. 2011. 4: 34-37.

3. Jesús Carlos Ruvalcaba Ledezma y Sandra Yazmín Cortés Ascencio. El contexto socio-ambiental y la educación para la salud en San Andrés Paxtlán, Oaxaca, México. Xihmai. 2013; 8 (16): 1-30.

4. Jesús Carlos Ruvalcaba Ledezma y Sandra Yazmín Cortés Ascencio. El sistema de Salud Mexicano. ODOUS científica. 2012; 13 (1): 34- 42.

5. Apolonio Contreras J. Arroyo Ramírez M. Balderrama Díaz R. Goez Benumea R. González Espindola JA. Hernández Badillo $E$. Jiménez Oropeza SA. Mayorga Contreras BC. Ruvalcaba Ledezma JC. Sistema Nacional de Salud Mexicano. Boletín Educación para la salud, UAEH. 2015; 13 (1): 1-15.

6. Jesús Carlos Ruvalcaba Ledezma, Sandra Yazmín Cortés Ascencio, José Margarito Jiménez Mora.

Salud pública en México implicaciones para la enseñanza de la biología y las ciencias de la salud. Biografía: escritos sobre la enseñanza de la biología. 2013; 6(10): 51-58

7. Jesús Carlos Ruvalcaba Ledezma, Sandra Yazmín Cortés Ascencio, Regina Escamilla Violante, Ana Cortés Ascencio, Jorge Teodoro Chávez Pagola, Lorenzo Octavio Aguirre Rembao, Jeiry Toribio Jiménez. Gestión de la Salud Pública y políticas públicas para estimular estilos de vida saludables a nivel local y global. KASMERA. 2015; 43(1): 234250.

8. Hernández Medina Miriam Selene, Hernández Serrano Carolina, López González Ana Laura, Barragán López Norma, Islas Vega Iracema, Mariela Lizbeth Cobián Díaz, Reynoso Vázquez Josefina, Ruvalcaba Ledezma Jesús Carlos. Values-attributes needed to make decisions in Health, from the Essential Functions of Public 
Health. American Journal of Public Health Research. 2017; 5: 154-158.

9. Julio Frenk Mora. El futuro del Sistema de Salud en México.

https://www.youtube.com/watch?v=57od1j_aS-I, 2012.
10. Murayama Rendon, Ciro, Ruesga Benito, Santos Miguel, Hacia un Sistema Nacional Público de Salud en México, Programa Universitario de Estudios de Desarrollo UNAM 2016; 1: 19-98.

11. Eduardo González Pier. Economía de la trasformación del Sistema de Salud, Garceta Medica de México, 2012; 148: 533-544

Cite this Article: Estrada M.I., Huitzil H.L., Lazcano C.M., Márquez P.T., Trejo V.N.Y., Villanueva G.R.Y. (2018). Critical analysis of the reality of the Mexican Health System and the Organization of Health Systems in Mexico. Greener Journal of Epidemiology and Public Health, 6(2): 63-68, http://doi.org/10.15580/GJEPH.2018.2.022618027. 